\title{
Effect of roof painting of aviaries on thermal comfort, productive performance and physiological variables of broilers chickens
}

\author{
Efeito da pintura de telhado de aviários no conforto térmico, desempenho produtivo e \\ variáveis fisiológicas de frangos de corte
}

\section{VALADARES, Leonora Ribeiro ${ }^{1}$; MOREIRA, Joerley ${ }^{1}$; DALÓLIO, Felipe Santos ${ }^{2 *}$; GUIMARÃES, Maria Clara de Carvalho ${ }^{3}$; TINÔCO, Ilda de Fátima Ferreira ${ }^{2}$; VAZ, Diego Pereira $^{4}$; LIMA, Héder José D’Avilla ${ }^{5}$ ALBINO, Luiz Fernando Teixeira ${ }^{6}$}

\footnotetext{
${ }^{1}$ Universidade Federal dos Vales do Jequitinhonha e Mucuri, Faculdade de Ciências Agrárias, Departamento de Zootecnia, Diamantina, Minas Gerais, Brasil.

${ }^{2}$ Universidade Federal de Viçosa, Centro de Ciências Agrárias, Departamento de Engenharia Agrícola, Viçosa, Minas Gerais, Brasil.

${ }^{3}$ Universidade Federal dos Vales do Jequitinhonha e Mucuri, Faculdade de Ciências Agrárias, Departamento de Agronomia, Diamantina, Minas Gerais, Brasil.

${ }^{4}$ Universidade Federal de Minas Gerais, Escola de Veterinária, Programa de Pós-Graduação em Ciência Animal, Belo Horizonte, Minas Gerais, Brasil.

${ }^{5}$ Universidade Federal de Mato Grosso, Faculdade de Agronomia, Medicina Veterinária e Zootecnia, Departamento de Zootecnia e Extensão Rural, Cuiabá, Mato Grosso, Brasil.

${ }^{6}$ Universidade Federal de Viçosa, Centro de Ciências Agrárias, Departamento de Zootecnia, Viçosa, Minas Gerais, Brasil.

*Endereço para correspondência: felipesantos181@hotmail.com
}

\section{SUMMARY}

The objective this study was to evaluate the thermal comfort, performance and the physiological variables of 21-42 day of age broiler chickens housed in aviaries with painted and not painted fiber cement roof. A completely randomized design was used in a split-plot design where the plots were composed of the sheds (painted and not painted roof) and the subplots were the evaluation hours $(6 \mathrm{~h} 00,9 \mathrm{~h} 00,12 \mathrm{~h} 00$, $15 \mathrm{~h} 00$ and $18 \mathrm{~h} 00$ ) for a 22 -day data collection, considered as the replicates. It was observed that the external painting in white of the roof provided improvements inside the shed for airtemperature $(\mathrm{Ta})$, roof temperature (Tr) and the thermal load of radiation (TLR). The relative humidity $(\mathrm{RH})$ and the Globe-Temperature-Humidity-Index (GTHI) varied only according to the collection times. The exterior painting of the roof had no effect on the physiological variables of the broilers. Productivity performance indexes and financial compensation per lot were better for the roof painted shed. As a result, fiber cement roof painted in white is recommended in aviaries located in hot climates, such as the region in this study.

Key words: ambience, cover, bioclimatic indexes, fiber cement, poultry

\section{RESUMO}

Objetivou-se avaliar o conforto térmico, o desempenho e as variáveis fisiológicas de frangos de corte alojados em aviários com e sem pintura de telhados de fibrocimento, no período de 21 a 42 dias de idade. Foi utilizado o delineamento inteiramente casualizado, em arranjo com parcela subdividida, onde as parcelas foram compostas pelos galpões (com e sem pintura de telhado) e as subparcelas os horários de avaliação $(6,9,12,15$ e $18 \mathrm{~h}$ ) ao longo de 22 dias de coleta de dados, considerados como repetição. Observou-se que a pintura externa do telhado na cor branca, proporcionou melhorias no interior do galpão para a temperatura ambiente $(\mathrm{Ta})$, temperatura de telhado ( $\mathrm{Tt}$ ) e na carga térmica de radiação (CTR). A umidade relativa (UR) e o índice de 
temperatura de globo negro e umidade (ITGU) variaram apenas em função dos horários de coleta. Não houve efeito da pintura externa do telhado nas variáveis fisiológicas das aves. Os índices de desempenho produtivo $\mathrm{e} a$ remuneração financeira por lote foram melhores para o galpão com pintura de telhado. Assim, recomenda-se a pintura externa em telhados de fibrocimento, na cor branca, em aviários localizados em ambientes de clima quente, como a região em estudo.

Palavras-chave: ambiência, avicultura, cobertura, índices bioclimáticos, fibrocimento

\section{INTRODUCTION}

Environmental management and its adaptations by controlling climatic variables associated to thermal comfort indexes, if properly managed, promotesbroiler performance. The facilities should ensure the maintenance of homeothermy for animal thermal comfort and ensure the animal well-being in production, with the minimum expenditure of energy (PASSINI et al., 2013). So, alternatives to reduce the amount of heat inside the aviaries, especially those located in hot climate regions are necessary.

The roof is anextremely important element in the poultry facility for controlling the total incident heat and for the maintenance of satisfactory bioclimatic indexes, since it receives and absorbs a great part of the direct solar radiation (SAMPAIO et al., 2011; SILVA et al., 2015a). In Brazil, a considerable number of the aviaries have asbestos roof due to its low acquisition price, implantation and maintenance costs (ABREU et al., 2011). However, this type of cover may absorb more heat and transmit the surplus to the inner part of the building (HERNÁNDEZ-PÉREZ et al., 2014).As a result, it is important to propose adaptive mechanisms, preferably of low cost, to improve the ambience and acclimatization of broilers raised in hot climate regions (SILVA et al., 2015b). The external painting on aviary roofs is a measure of easy implantation and inexpensive to the producer in addition to promoting the thermal comfort and performance indexes of the broilers (PASSINI et al., 2012; 2013).

Brazil has great climatic amplitude and the expansion of the poultry farming occurred practically all over the national territory. So, the evaluation of the microclimate in relation to bioclimatic characterization in aviaries located in the different broiler producing regions is of paramount importance (SANTOS et al., 2014; DALÓLIO et al., 2016). This may become more evident in poultry buildings with different types of cover, associated or not with external painting, as well as its effect on performance, on the physiological variables of the broilers and on the poultry farmer's financial remuneration. Consequently, the objective of this studywas to evaluate the thermal comfort, performance and physiological variables of broiler chickens housed in conventional poultry shed with and without external asbestos cement roofing the period from 21 to 42 days of age.

\section{MATERIALAND METHODS}

The experiment was carried out on the commercial farm Nossa Senhora Aparecida, located in the municipality of Jequitibá, state of Minas Gerais, $19^{\circ} 13^{\prime} 42^{\prime \prime}$ South latitude and $44^{\circ} 2^{\prime} 17^{\prime \prime}$ West longitude, in the Meso-region of Sete Lagoas, state of Minas Gerais, Brazil. This region has $5.20 \mathrm{kWh} / \mathrm{m}^{2} /$ day of global solar radiation, with an average annual maximum temperature of $29.2^{\circ} \mathrm{C}$ 
(REIS \& TIBA, 2016). According to the classification of Köppen, the climate of the region is Cwa, characterized as humid temperate climate with dry winter and hot summer.

Two conventional, identical, east-west oriented aviaries were used. Each aviary was $12 \mathrm{~m}$ in width and $140 \mathrm{~m}$ in length, with $0.20-\mathrm{m}$ side walls and $3.50-\mathrm{m}$ celing, covered with asbestos cement roofs, concrete floor, sides protected with galvanized wire screens and polyethylene hand curtains in yellow with lining also in yellow and southeastern dominant winds. The artificial housing system, positive ventilation associated with nebulization, consisted of three fan lines, with ten fans in each line, and a spray system with three nebulizer lines. In both sheds, 19300 Cobb 500 broilers, mixed sex, were housedat the density of 11.5 broilers $/ \mathrm{m}^{2}$. The experiment started when the broilers were 21 days of age. In addition, one of the aviaries was painted with two coats of acrylic latex paint in white, applied on the outer part of the roof, after previous cleaning of the cover to be painted. According to the manufacturer, this paint has reflectance and absorbance indexes of $75 \%$ and $25 \%$, respectively, on ceramic tiles basis. The management and feeding of the broilers were carried out according to the recommendations of the integrating company of the region, being the same for both sheds.

Environmental variables and the thermal comfort indexes were analyzed in a completely randomized experimental design, in asplit-plot arrangement where the plots were the two aviaries (with or without painted roof) and in the subplots, the five hours of data collection $(6 \mathrm{~h} 00$, $9 \mathrm{~h} 00, \quad 12 \mathrm{~h} 00, \quad 15 \mathrm{~h} 00$ and 18h00), evaluated for 22 days, considered as replicates. These hours were stipulated in order to verify the effect of the roof painting on the comfort of the broilers during the day, because at night, the temperatures are milder inside the building.

Data on dry bulb temperature (Tdb), dew point temperature (Tdp), black globe temperature (Tbg), roof temperature (Tr), roof lining temperature ( $\mathrm{Trl})$, litter temperature ( $\mathrm{Tl})$, wind velocity $(\mathrm{Wv})$ and relative humidity $(\mathrm{RH})$ inthe sheds were collected daily at three distinct and equidistant points - initial third $(35 \mathrm{~m})$, middle third $(70 \mathrm{~m})$ and final third (105 $\mathrm{m})$ - located at the center of each shed, to remove the border effect, carried out at $6 \mathrm{~h} 00,9 \mathrm{~h} 00,12 \mathrm{~h} 00,15 \mathrm{~h} 00$ and $18 \mathrm{~h} 00$. Data loggers of the Instrutherm ${ }^{\circledR}$ HT-500 model were used to collect the variables $\mathrm{Tdb}$, Tdp and RH. Wind velocity was collected through the use of a digital propeller anemometer. For the collection of the Tbg, black globe thermometers were installed in each aviary and model 5110 Instrutherm ${ }^{\circledR}$ mercury thermometers were arranged in the three positions (initial, middle and final third) $0.30 \mathrm{~m}$ from the litter corresponding to the center of mass of broilers. The Tr, Trl and Tl, were collected using a double laser sight thermometer with $\pm 1.0^{\circ} \mathrm{Caccuracy}$.

Thermal comfort indexes were calculated from the collection of climatic variables using Equations 1,2and 3.

GTHI (Globe-Temperature-HumidityIndex) (BUFFINGTON et al., 1981) (1):

$$
\mathrm{GTHI}=\mathrm{Tbg}+0.36 \mathrm{Tdp}+41.5
$$

where:

$\mathrm{Tbg}=$ black globe temperature, in ${ }^{\circ} \mathrm{C}$ $\mathrm{Tdp}=$ dew point temperature, in ${ }^{\circ} \mathrm{C}$ TLR (Thermal-Load-Radiation) (ESMAY, 1969) (2):

$$
\mathrm{RTL}=\sigma(\mathrm{ART})
$$

where:

$\mathrm{RTL}=$ radiantthermal load, $\mathrm{W} \mathrm{m} \mathrm{m}^{-2}$ 
$\sigma=$ Stefan-Boltzmann's constant, $5.67 \times 10^{-8} \mathrm{~W} \mathrm{~m}^{-2} \mathrm{~K}^{-4}$

$$
\mathrm{ART}=100[2.51 *(\mathrm{~V}) .5 *(\mathrm{Tbg}-\mathrm{Tdbs})+(\mathrm{Tbg} / 100)](3)
$$

where:

$\mathrm{v}=$ air velocity, $\mathrm{ms}^{-1}$

Tbg = black globe temperature, $\mathrm{K}$

$\mathrm{Tdb}=$ dry bulb temperature, $\mathrm{K}$

The performance was evaluated using the results of body weight (BW), average feed intake (FI), average daily gain (ADG), feed conversion ratio (FCR) and viability (VB) provided by the integrating company at the lot removal hour. After that, at payment, the company provided the data of productive efficiency index (PEI) and gross remuneration of each lot (GR).

In relation to the evaluation of the physiological variables, the rectal and surface temperatures of the broilers were measured. Those variables were collected weekly at 21, 28, 35 and 42 days of age, at $13 \mathrm{~h} 00$. For that, three males and three females from three sections of each aviary (initial, middle and final third) were used. To measure the rectal temperature, a $\pm 0.1-^{\circ} \mathrm{C}$ precison digital clinical thermometer was introduced in the cloaca of the broilers until stabilization of the reading. The surface temperature of the back of the broilers was mesured using an infrared laser thermometer, model TI-870 Instrutherm $^{\circledR}$, with resolution of $0.1^{\circ} \mathrm{C}$ and accuracy of \pm $1.0^{\circ} \mathrm{C}$, at the distance of approximately $10 \mathrm{~cm}$ away from the broilers.

Data on thermal environment, comfort indexes and the physiological variables were submitted to analysis of variance using SAS software (2002). Averages of the aviaries were compared by the Tukey's test, whereas the interaction and effects of the evaluation hours were evaluated by means of regression analysis, both at $5 \%$ of probability. The interpretation of the performance data of broilers and gross remuneration of the lots housed in the two types of sheds was performedin a descriptive way.

\section{RESULTS AND DISCUSSION}

An interaction $(\mathrm{P}<0.05)$ was observed between the painted or not painted roof shed and data collection time for air temperature (Table 1).

The external painting of the roof provided a lower air temperature in the $9 \mathrm{~h} 00-1500 \mathrm{~h}$ range, compared to the not painted shed (Figure 1). However, this reduction was not sufficient to keep the 21-42 day-ofage broiler chickens in the recommended thermal comfort zone, which is $18^{\circ}-24^{\circ} \mathrm{C}$ (COBB-VANTRESS, 2013). Similar behavior was observed by Fiorelli et al. (2010) and Passini et al. (2013) when evaluating different cover materials of poultry buildings, with and without external roof painting. The difficulty in achieving suitable air temperatures for broilers may be justified by the fact that most of the aviaries in Brazil are open. This makes the sheds to behave like a thermodynamic system in constant interaction, where it absorbs, reflects and transmits the heat from the environment into the inner part of the building through multifactorial causes.

After all, the air temperature inside the building is directly related to the heat produced by the animals, to the heat that is absorbed through direct and indirect solar radiation, to the heat exchanged by the roofing materials, walls, floor and litter and to the thermal changes caused by natural or artificial ventilation (KAWBATA et al., 2005). 
Table 1. Average values ofair temperature (Ta), relative humidity $(\mathrm{RH})$, roof temperature $(\mathrm{Tr})$, roof lining temperature $(\mathrm{Trl})$ and litter temperature $(\mathrm{Tl})$ in two broiler conventionalpainted (PS) and not painted roof (NPS) shed, at different collection hours $(\mathrm{H})$

\begin{tabular}{|c|c|c|c|c|c|}
\hline SV & $\mathrm{Ta}\left({ }^{\circ} \mathrm{C}\right)$ & RH (\%) & $\operatorname{Tr}\left({ }^{\circ} \mathrm{C}\right)$ & $\operatorname{Trl}\left({ }^{\circ} \mathrm{C}\right)$ & $\mathrm{Tl}\left({ }^{\circ} \mathrm{C}\right)$ \\
\hline \multicolumn{6}{|l|}{ Shed } \\
\hline PS & 26.69 & 48.78 & $27.75^{\mathrm{a}}$ & 27.34 & 27.80 \\
\hline NPS & 26.83 & 47.09 & $33.62^{\mathrm{b}}$ & 28.91 & 27.24 \\
\hline $\mathrm{P}$ value & 0.8163 & 0.1513 & - & 0.1564 & 0.1553 \\
\hline \multicolumn{6}{|l|}{ Hour } \\
\hline $6 \mathrm{~h} 00$ & 22.39 & 64.41 & 30.23 & 27.60 & 27.38 \\
\hline $9 \mathrm{~h} 00$ & 27.25 & 45.59 & 29.87 & 27.70 & 27.39 \\
\hline $12 \mathrm{~h} 00$ & 29.08 & 41.12 & 31.52 & 28.56 & 27.75 \\
\hline $15 \mathrm{~h} 00$ & 29.02 & 40.58 & 30.47 & 28.29 & 27.81 \\
\hline $18 \mathrm{~h} 00$ & 26.05 & 47.99 & 31.32 & 28.51 & 27.27 \\
\hline $\mathrm{P}$ value & - & - & 0.5589 & 0.1603 & 0.2036 \\
\hline $\mathrm{S} \times \mathrm{H}$ & $0.0401^{*}$ & 0.6882 & 0.9959 & 0.1603 & 0.5966 \\
\hline CV (\%) & 4.75 & 9.82 & 17.69 & 8.29 & 4.78 \\
\hline
\end{tabular}

$\mathrm{SV}=$ sources of variation; $\mathrm{CV}(\%)=$ coefficient of variation.

*Existing integration between type of shed (S) and data collection hour(H); Means followed by different letters are statically different from each other at $5 \%$ in the same column by the test of Tukey.

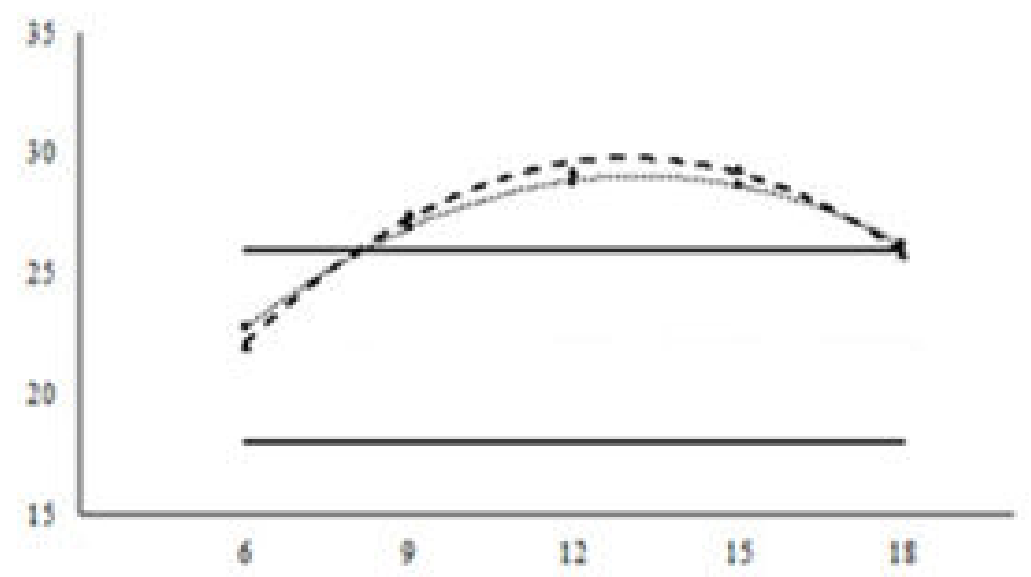

Figure 1 Values of average and regression equations of air temperature $\left({ }^{\circ} \mathrm{C}\right)$ at 21-42 day-of-age period as a function of collection hours $(\mathrm{h})(6 \mathrm{~h} 00$, $9 \mathrm{~h} 00,12 \mathrm{~h} 00,15 \mathrm{~h} 00$ and $18 \mathrm{~h} 00)$ in the painted $(\mathrm{PS})(\ldots .).\left(\mathrm{T}_{\mathrm{PS}}=7.7991+\right.$ $\left.3.2247 \mathrm{H}-0.1223 \mathrm{H}^{2} ; \mathrm{R}^{2}=0.50\right)$ and not-painted roof shed (NPS) (-----) $\left(\mathrm{T}_{\mathrm{NPS}}=3.3564+4.0658 \mathrm{H}-0.1563 \mathrm{H}^{2} ; \mathrm{R}^{2}=0.58\right)$ and schematic representation of the comfort range recommended by Cobb-Vantress $(2013)(====)$

The RH inside the sheds was influenced only by the collection hours during the day over the experimental period and it was out of that recommended by CobbVantress (2013) (50-70\%), decreasing in the $6 \mathrm{~h} 00-1500 \mathrm{~h}$ period and increasing 
until $18 \mathrm{~h} 00$. According to Oliveira et al. (2006), RH should always be evaluated in conjunction with air temperature, since the ability of broilers to withstand heat is inversely proportional to moisture content. Above all, the higher the $\mathrm{RH}$, the greater the difficulty of the broiler to remove the endogenous heat through the respiratory tracts, through latent mechanisms. This results in an increase in the respiratory rate and energy expenditure due to raise in the muscle contraction, causing severe hyperthermia (LARA \& ROSTAGNO, 2013). In addition, confined broilers are limited to adjustments necessary to dissipate metabolic heat, resulting in impairmentin expressing the ethological behaviors inherent to broilers, directly influencing their well-being.

The Tt was influenced by external paint in white, with an average reduction of $17.45 \%$ and $5.9^{\circ} \mathrm{C}$, in relation to the notpainted roof shed that indicates an enhancement in absorbance and reflectance for fiber cement. Similar results were observed by Sarmento et al. (2005), when evaluating cement roof painted in white with differences of $18 \%$ and $9{ }^{\circ} \mathrm{C}$.

The $\mathrm{Trl}$ and $\mathrm{Tl}$ of the sheds were not affected by the exterior painting of the roofs or at the different observation hours (Table 1). According to Cavalcanti et al. (2009), this was expected because the air layer formed in the lining has low thermal conductivity and low radiation absorption coefficient, being resistant to the passage of heat. In relation to $\mathrm{Tl}$, it tends to be increased as the air temperature of the buildings increases. This is attributable to the higher consumption of water by broilers with elimination of more liquid excreta, which may result in fermentative litter processes (LAVOR et al., 2008). Such fact was not observed in the present study.

An interaction $(\mathrm{P}<0.05)$ was found for roof painting of the sheds and the different data collectionhour for TLR (Table 2).

Table 2. Average values of thermal load of radiation(TLR) and Globe-TemperatureHumidity-Index (GTHI) in two commercial broiler sheds withpainted roof (PS) and not painted roof (NPS) at different collection hours (H)

\begin{tabular}{lcc}
\hline SV & TLR $\left(\mathrm{W} / \mathrm{m}^{2}\right)$ & GTHI \\
\hline Shed & & \\
PS & 478.25 & 74.25 \\
NPS & 486.18 & 74.74 \\
\hline P value & 0.1841 & 0.5882 \\
\hline Hour & & 69.68 \\
\hline $6 \mathrm{~h} 00$ & 436.30 & 74.48 \\
$9 \mathrm{~h} 00$ & 472.99 & 77.14 \\
$12 \mathrm{~h} 00$ & 507.19 & 77.19 \\
$15 \mathrm{~h} 00$ & 511.88 & 73.98 \\
$18 \mathrm{~h} 00$ & 482.71 & $<0.001$ \\
\hline P value & & 0.1869 \\
\hline S x H interaction & $0.0413^{*}$ & 1.31 \\
\hline CV $(\%)$ & 3,81 &
\end{tabular}




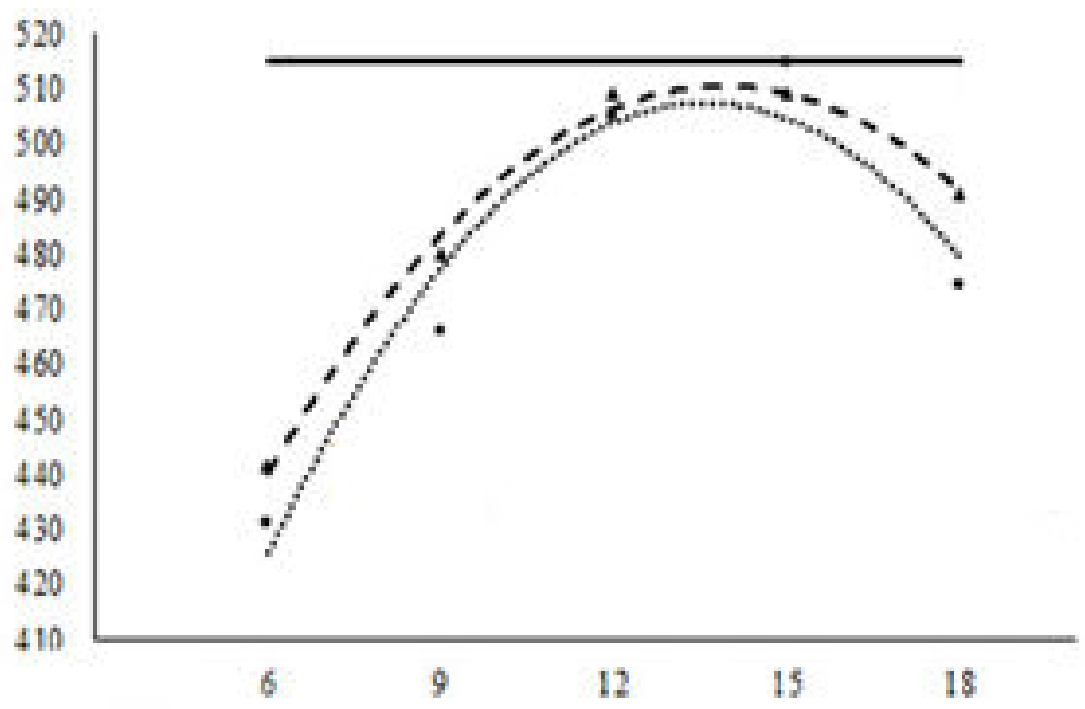

Figure 2. Average values and regression equations of the thermal load of radiation (TLR-W/ $/ \mathrm{m}^{2}$ ) in the $21-42$ day of age period, according to the data collection hours $(\mathrm{H})(6 \mathrm{~h} 00$, 9h00, $12 \mathrm{~h} 00,15 \mathrm{~h} 00$ and $18 \mathrm{~h} 00)$ in the painted roof (PS) (...) (TLR $\left.\mathrm{PS}=243,9304+38,8430 \mathrm{H}-1,4308 \mathrm{H}^{2} ; \mathrm{R}^{2}=0.54\right)$ and not painted roof shed (NPS) (---) $\left(\right.$ TLR ${ }_{\mathrm{NPS}}=292,6670+$ $31,3595 \mathrm{H}-1,1284 \mathrm{H}^{2} ; \mathrm{R}^{2}=0.51$ ) and limit of the TLR value recommended by Cassiano et al. (2009) for fiber cement roof

Overall, TLR values increased from $6 \mathrm{~h} 00$ to $15 \mathrm{~h} 00$, with subsequent reduction until $18 \mathrm{~h} 00$ (Figure 2). This occurs as a function of direct solar radiation, which reaches the highest values near $15 \mathrm{~h} 00$, when the sun is more perpendicular to the local horizon plane, and as a function of the radiation of long waves emitted by the neighborhood (PASSINI et al. al., 2013). The average TLR values observed in this study are close to those verified by Moraes et al. (1999) and Nääs et al. (2001), $487.60 \mathrm{~W} . \mathrm{m}^{2}$ and $475.19 \mathrm{~W} . \mathrm{m}^{2}$, respectively, in sheds with externally white painted fiber cement roof. Sampaio et al. (2011) reported that the TLR for white-painted asbestos fiber cement roof compared to ceramic tiles have similar thermal performances. Passini et al. (2013) stated that the external painting of asbestos fiber cement roofs,coupled or not to artificial ventilation systems, promotes a reduction in TLR values, with a reduction in the amount of heat inside the poultry building.

The GTHI values ranged from 69.68 to 77.19 during the experimental period (Table 2). An increase occurred until the $15 \mathrm{~h} 00$ and then, the value declined, and in the $12 \mathrm{~h} 00-15 \mathrm{~h} 00$ interval, the values extrapolated the comfort range from 69 to 77 , which is recommended by Oliveira et al. (2006) for 21-42 day of age broiler. Although the GTHIis used for measuring thermal comfort of the animal, it only considers temperature and humidity variables. Air temperature is a measure of the sensible heat content only of the atmosphere, while the humidity estimates the latent heat. Whilst both are important for the process of heat exchange between animals and environment, thermal radiation plays a fundamental role as a thermal stress factor for animals (SILVA 
\& MAIA, 2013). Indeed, solar radiation is of great magnitude in an intertropical region, where the average radiant temperature is generally higher than the air temperature (SILVA, 2008). Among the indices evaluated in the present study, the TLR is the most adequate to verify the heat in the building. Thus, the low applicability of the GTHI to assess the comfort of broiler chickens is emphasized, as well as the plumage, feather and skin characteristics of the broiler, the wind speed coming into the building and the intrinsic capacity of each species to eliminate endogenous heat are other variables that must be regarded for the elaboration of thermal comfort indexes for broilers.

The rectal temperature and the surface temperature of the broilers are important physiological variables to verify whether the animal is in comfort (GUIMARÃES et al., 2014; RODRIGUES et al., 2016). No effect $(\mathrm{P}<0.05)$ of the roof paint was observed for the physiological variables. The rectal temperature of the broilers ranged $(\mathrm{P}<0.05)$ only as a function of the collection site, being higher for the broilers located in the final third of the shed.

Table 3. Average values of rectal temperature $\left({ }^{\circ} \mathrm{C}\right)$ and superficial temperature $\left({ }^{\circ} \mathrm{C}\right)$ of broilers housed in two types of commercial sheds, painted roof (PS) and not painted roof shed (NPS), in the 21-42 day-of-age period

\begin{tabular}{lcc}
\hline SV & Rectal temperature $\left({ }^{\circ} \mathrm{C}\right)$ & Surface temperature $\left({ }^{\circ} \mathrm{C}\right)$ \\
\hline Shed (S) & & \\
\hline PS & 41.52 & 33.46 \\
NPS & 41.45 & 33.44 \\
\hline Shed local (SL) & & 33.75 \\
\hline Initial third & $41.33^{\mathrm{b}}$ & 32.77 \\
Medium third & $41.52^{\mathrm{ab}}$ & 33.83 \\
Final third & $41.61^{\mathrm{a}}$ & 0.9930 \\
\hline $\mathrm{S} x \mathrm{SL} *$ & 0.7508 & 4.19 \\
\hline $\mathrm{CV}(\%)$ & 0.48 & \\
\hline $\mathrm{SV}=$ sources of variation; CV $(\%)=$ Coefficient of variation; $*=$ existing interaction between shed type
\end{tabular}

(S) and local (SL)

The final third of conventional poultry sheds, with positive ventilation associated with nebulization is likely to become the zone with the greatest environmental stress, because a greater accumulation of gases, dust and hot air occur in this place. However, the rectal temperature values observed in the present study fluctuated within the limit recommended by Ryu et al. (2016), from 41 to $42^{\circ} \mathrm{C}$. The absence of variation in the surface temperature can be justified by the fact that this variable was measured on the back of the broilers. Despite the trend that occurs in warm environmentsto the increase in the surface temperature of broilers by the rise in the peripheral blood circulation in an attempt to dissipate endogenous heat through sensitive processes, this occurs more strongly only in tissues not covered by feathers such as feet, crest and wattles (DALÓLIO et al., 2015). Measurement of the physiological variables only once in each experimental week may have contributed to the absence of the effect.

The external paint of the roof provided an enhanced performance of the broilers (Table 4). However, it was still lower 
than the expected performance for the line, except for the characteristics of average feed intake and feed conversionratio. Similar results were observed by Passini et al. (2012) who verified an improvement in the average weight gain for broilers reared in sheds with asbestos fiber cement roof painted with external reflexive painting.

Table 4. Average values of body weight (BW), average daily gain (ADG), average feed intake (FI), feed conversion ratio (FCR), viability (VB) and productive efficiency index (PEI) and gross financial remuneration of the lot (GR) of 43day-of-age broilers housed in two commercial sheds with painted (PS) and not painted roof (NS)

\begin{tabular}{lccccccc}
\hline Parameter & BW $(\mathrm{g})$ & ADG $(\mathrm{g})$ & FI $(\mathrm{g})$ & FCR $(\mathrm{g} / \mathrm{g})$ & VB $(\%)$ & PEI & GR $(\mathrm{R} \$)$ \\
\hline PS & 2707 & 62.95 & 4253 & 1.65 & 95.09 & 362 & $13,994.29$ \\
NS & 2700 & 62.79 & 4404 & 1.71 & 95.50 & 351 & $12,636.25$ \\
Cobb 500* & 2732 & 65.00 & 4659 & 1.71 & 96.00 & 364 & - \\
\hline
\end{tabular}

*Expected productive performance according to Cobb 500 line guidelines (COBB-VANTRESS, 2013).

The productive efficiency index (PEI) and the gross financial remuneration of the lot (GR) were 3.13 and $11.07 \%$ higher for the roof painted shed, respectively. This was because the increase in PEI and GR directly depends on the progress in the productive parameters that were provided by the improvement in the interior ambience of the roof painted shed. In addition, the region integrating company pays a bonus of $\mathrm{R} \$ 0.01 /$ broiler for each unit improvement in feed conversion ratio, based on the average efficiency of the Cobb 500 line. According to Simões et al. (2015), the highest financial remuneration of the broiler flock associated with the enhancement in performance is essential for integrated poultry to become competitive and profitable instead of being a risky activity due to the high cost involved in the acquisition and implantation of the sheds by poultry farmers.

Therefore, external painting of fiber cement roofs in white is recommended for conventional aviaries located in hot climate regions as an additional lowcost alternative tool to improve thermal comfort, performance and financial profitability per housed lot.

\section{ACKNOWLEDGEMENTS}

The authors thank CAPES, CNPq, FAPEMIGand UFVJM for their support on the study execution.

\section{REFERENCES}

ABREU, P.G.; ABREU, V.M.N.; COLDEBELLA, A.; LOPES, L.S.; CONCEIÇÃO, V.; TOMAZELLI, I.L.

Análise termográfica da temperatura superficial de telhas. Revista Brasileira de Engenharia Agrícola e Ambiental, v.15, p.1193-1198, 2011.

BUFFINGTON, D.E.; COLAZZOAROCHO, A.; CATON, G.H. Black globehumiditycomfort index (BGHI) as comfortequation for dairycows.

Transaction of the ASAE, v.24, p.711714, 1981. 
CAVALCANTI, M.A.V.; MENDES, J.U.L.; CAVALCANTI, B.T.V.; SILVEIRA, F.F. Comparative analysis of the efficiency of thermal systems built with reflective insulators with and without vacuum. Thermal

Engineering, v.8, p.15-20, 2009.

\section{COBB-VANTRESS.Broiler}

management Guide. Arkansas: CobbVantress USA, 2013. 73p.

DALÓLIO, F.S.D.; ALBINO, L.F.T.; LIMA, H.J.D.; SILVA, J.N.;

MOREIRA, J. Heat stress and vitamin E in diets for broilers as a mitigating measure. Acta Scientiarum. Animal Sciences, v.37, p.419-427, 2015.

DALÓLIO, F.S.D.; MOREIRA, J.; COELHO, D.J.R.; SOUZA, C.F. Caracterização bioclimática de um galpão experimental de criação de frangos de corte na região de Diamantina-MG. Engenharia na Agricultura, v.24, p.22-31, 2016.

\section{ESMAY,M.L. Principlesof animal environment. Westport, CT Abi., 1969. $325 p$.}

FIORELLI, J.; FONSECA, R.; MORCELLI, J.A.B.; DIAS, A.A. Influência de diferentes materiais de cobertura no conforto térmico de instalações para frangos de corte no oeste paulista. Engenharia Agrícola, v.30, p.986-992, 2010.

GUIMARÃES, M.C.C.; FURTADO, D.A.; NASCIMENTO, J.W.B.; TOTA, L.C.A.; SILVA, C.M.; LOPES, K.B.P. Efeito da estação do ano sobre o desempenho produtivo de codornas no semiárido paraibano. Revista

Brasileira de Engenharia Agrícola e Ambiental, v.18, p.231-237, 2014.
HERNÁNDEZ-PÉREZ, I.; ÁLVAREZ, G.; XAMÁN, J.; ZAVALLAGUILLÉN, I.; ARCE, J.; SIMÁ, E.

Thermal performance of reflective materials applied to exterior building components $-a$ review. Energy and Buildings, v.80, p.81-105, 2014.

KAWBATA, C.Y.; CASTRO, R.C.; SAVASTANO JÚNIOR, H. Índices de conforto térmico e respostas fisiológicas de bezerros da raça holandesa em bezerreiros individuais com diferentes coberturas. Engenharia Agrícola, v.25, p.598-607, 2005.

LARA, L.J.; ROSTAGNO, M.H. Impact of heat stress on poultry production. Animals (Basel), v.3, p.356-369, 2013.

LAVOR, C.T.B.; FERNANDES, A.A.O.; SOUSA, F.M. Efeito de materiais isolantes térmicos em aviários no desempenho de frango de corte.

Revista Ciência Agronômica, v.39, p.308-316, 2008.

MORAES, S.R.P.; TINÔCO, I.F.F.; BAÊTA, F.C.; CECON, P.R. Conforto térmico em galpões avícolas, sob coberturas de cimento-amianto e suas diferentes associações. Revista Brasileira de Engenharia Agrícola e Ambiental, v.3, p.89-92, 1999.

NÄÄS,I.A.; SEVEGNANI, K.B.; MARCHETO, F.G.; ESPELHO, J.C.C.; MENEGASSI, V.; SILVA, I.J.O. Avaliação térmica de telhas de composição de celulose e betumem, pintadas de branco, em modelos de aviários com escala reduzida.

Engenharia Agrícola, v.21, p.121-126, 2001. 
OLIVEIRA, R.F.M.; DONZELE, J.L.; ABREU, M.L.T.; FERREIRA, R.A.; VAZ, R.G.M.V.; CELLA, O.S. Efeitos da temperatura e da umidade relativa sobre o desempenho e o rendimento de cortes nobres de frangos de corte de 1 a 49 dias de idade. Revista Brasileira de Zootecnia, v.35, p.797-803, 2006.

PASSINI, R.; ARAÚJO, M.A.G.; ALMEIDA, E.A.; YASUDA, V.M. Evaluation of reflective painting of the roof and artificial ventilation on performance and carcass yield of broilers.

Revista Brasileira de Zootecnia, v.41, p.1769-1774, 2012.

PASSINI, R.; ARAÚJO, M.A.G.; YASUDA, V.M.; ALMEIDA, E.A. Intervenção ambiental na cobertura e ventilação artificial sobre índices de conforto para aves de corte. Revista Brasileira de Engenharia Agrícola e Ambiental, v.17, p.333-338, 2013.

REIS, R.J.; TIBA, C. Atlas solarimétrico de Minas Gerais. Belo Horizonte, MG: Futura Express, 2016. 236p.

RODRIGUES, L.R.; FURTADO, D.A.; COSTA, F.G.P.; NASCIMENTO, J.W.B.; CARDOSO, E.A. Thermal comfort index, physiological variables and performance of quailsfed with protein reduction. Revista Brasileira de Engenharia Agrícola e Ambiental, v. 20, p. 378-384, 2016.

RYU, S.T.; PARK, B.S.; BANG, H.T.; KANG, H.K.; HWANGBO, J. Effects of anti-heat diet and inverse lighting on growth performance, immune organ, microorganism and short chain fatty acids of broiler chickens under heat stress.

Journalof Environmental Biology,v. 37, p. 185-192, 2016.
SAMPAIO, C.A.P.; CARDOSO, C.O.; SOUZA, G.P. Temperaturas superficiais de telhas e sua relação com o ambiente térmico. Engenharia Agrícola, v.31, p.230-236, 2011.

SARMENTO, L.G.V.; DANTAS, R.T.D.; FURTADO, D.A.; NASCIMENTO, J.W.B.; SILVA, J.H.V. Efeito da pintura externa do telhado sobre o ambiente climático e o desempenho de frangos de corte. Revista Agropecuária Técnica, v.26, p.152-159, 2005.

SAS Institute: SAS: user'sguide: statistics. Cary, 2002.

SILVA, R.G. Biofísica ambiental: os animais e seu ambiente. Jaboticabal: FUNEP, 2008. 386p.

SILVA, R.G.; MAIA, A.S.C. Principles of Animal Biometeorology. Alemanha: Springer, 2013. 264p.

SILVA, K.C.P.; CAMPOS, A.T.; YANAGI JUNIOR, T.; CECCHIN, D.; LOURENÇONI, D.; FERREIRA, J.C.

Reaproveitamento de resíduos de

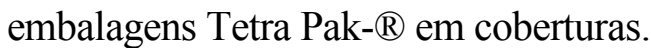

Revista Brasileira de Engenharia Agrícola e Ambiental, v.19, p.58-63, 2015a.

SILVA, M.G.; MARTIN, S.; OLIVEIRA, C.E.G.; MOSCON, E.S. DAMASCENO, F.A. Desempenho térmico de tipos de coberturas no interior de modelos reduzidos de galpões avícolas. Energia na Agricultura, v.30, p.269-275, 2015b.

SIMÕES, D.; RIBEIRO, J.P.; GOUVEIA, P.R.; SANTOS, J.C. Economical and financial analysis of aviaries for the integration of broilers under conditions of risk. Ciência e Agrotecnologia, v.39, p.240-247, 2015a.

Receipt date: $23 / 02 / 2018$

Approval date: 22/06/2018 